\title{
Two new Stephanostomum-like cercariae (Digenea: Acanthocolpidae) from Nassarius dorsatus and N. olivaceus (Gastropoda: Nassariidae) in Central Queensland, Australia
}

\author{
LEONIE J. BARNETT ${ }^{1}$, TERRENCE L. MILLER ${ }^{2} \&$ THOMAS H. CRIBB ${ }^{3}$ \\ ${ }^{\prime}$ Centre for Environmental Management, CQUniversity Australia, Bruce Highway, North Rockhampton, Queensland 4702, Australia. \\ E-mail: l.barnett@cqu.edu.au \\ ${ }^{2}$ Biodiversity Program, Queensland Museum, PO Box 3300, South Brisbane, Queensland 4101, Australia. \\ E-mail: terrence.miller@qm.qld.gov.au \\ ${ }^{3}$ Centre for Marine Studies and Department of Microbiology and Parasitology, The University of Queensland, Brisbane, Queensland \\ 4072, Australia.E-mail: t.cribb@uq.edu.au
}

\begin{abstract}
Two new Stephanostomum-like cercariae, Cercaria capricornia VII and Cercaria capricornia VIII (Digenea: Acanthocolpidae), are described from the nassariid gastropods Nassarius dorsatus and Nassarius olivaceus collected from the intertidal zone in the Capricornia region of Central Queensland, Australia. Morphological analysis of these new cercariae was augmented with DNA sequence data from the large subunit (LSU) ribosomal DNA region to aid in identification. Bayesian inference analysis of the LSU rDNA revealed that these putative acanthocolpid cercariae nested well within a clade containing species of Stephanostomum, which along with morphological data, suggests they are species of Stephanostomum. Comparative analysis of LSU rDNA sequences also indicates that these two cercariae are not $S$. adlardi, S. bicoronatum, S. tantabiddii or $S$. cf. $u k u$, all species known from Australian fishes. The secondary structure of the internal transcribed spacer 2 (ITS2) rDNA region was inferred for these two cercariae using minimum free energy modelling algorithms. Both cercarial types displayed a four helix ITS2 secondary structure model and differed from each other by two compensatory base changes (CBCs) and nine hemi-CBCs.
\end{abstract}

Key words: Cercaria capricornia; Capricornia; Nassarius dorsatus; Nassarius olivaceus; LSU rDNA; large subunit ribosomal DNA; CBC; compensatory base change; ITS2; internal transcribed spacer 2

\section{Introduction}

The Acanthocolpidae Lühe, 1906 is a large family of digenean trematodes that infects the gastrointestinal tract of marine fishes. Asexual reproduction occurs in a range of gastropods and metacercariae infect the tissues of fishes which are then eaten by piscivores to complete the life cycle. Although 17 genera were recognised in the family by Bray (2005), Stephanostomum Looss, 1899, with over one hundred species, is by far the largest in the family and one of the largest in marine fishes (Cribb et al. 2002). Despite the size of the genus, the life cycles and cercarial stages have been characterised for only five species (Madhavi \& Shameem 1993). A single further Stephanostomum-like cercariae, Cercaria bengalensis VII Gnana Mani, 1994, has been described (Gnana Mani 1994). For such a large and important genus, the range of hosts infected and the morphological consistency of the intra-molluscan stages is of considerable interest.

The nassariid gastropods Nassarius dorsatus (Röding) and Nassarius olivaceus (Bruguière) are common scavengers in the intertidal mangroves of the Capricornia region in Central Queensland, Australia. There are ten probable acanthocolpid cercariae reported previously from nassariid gastropods. There are three species of Stephanostomum: those of Stephanostomum tenue (Linton, 1898) Linton, 1934 and Stephanostomum dentatum (Linton, 1900) Linton, 1940 (syn. Cercaria dipterocerca Miller and Northup, 1926) from Nassarius obsoletus Say (see Martin 1939; Stunkard 1961) and Stephanostomum cloacum (Srivastava, 1938) Manter \& 
Van Cleave, 1951 from Nassarius orissaensis (Preston) (see Madhavi \& Shameem 1993). Cercaria bengalensis VII was reported from Nassarius stolatus (Gmelin), and was described as closely resembling the cercariae of S. tenue and Stephanostomum caducum (Looss, 1901) Manter, 1934 (Gnana Mani 1994). Other cercariae reported from nassariids are Cercaria capricornia I-IV Barnett, Smales \& Cribb, 2008 from $N$. olivaceus and Cercaria capricornia V-VI Barnett, Smales \& Cribb, 2008 from N. dorsatus. This is a complex of six unusual cercariae which are morphologically very different from cercariae of Stephanostomum in that they have an unusual body shape including a ventral keel (Barnett et al. 2008). Other Stephanostomum cercariae are Stephanostomum baccatum (Nicoll, 1907) Manter, 1934 (syn. Cercaria neptunae Lebour, 1911) from Buccinum undatum Linnaeus, Neptunea decemcostata (Say) and Neptunea antiqua (Linnaeus) (see MacKenzie \& Liversidge 1975; Wolfgang 1955) and S. caducum from Euspira pulchella (Risso) (syn. Natica alderi Forbes) (see Køie 1978).

Here, we present two new acanthocolpid cercariae from $N$. dorsatus and $N$. olivaceus found as part of a study of the parasite fauna of these molluscs in Capricornia. Bayesian inference analysis of partial large subunit (LSU) ribosomal DNA (rDNA) was performed with the aim of exploring the integrity of the putative new cercarial types and their phylogenetic relationships with other acanthocolpid taxa. In addition, we sequenced the internal transcribed spacer 2 (ITS2) rDNA region for these two types and inferred their secondary structures to explore the homology of these structures to each other and to that known for other digeneans.

\section{Material and methods}

Host gastropod and parasite collection. Molluscs were collected by hand from mudflats at Sandy Point,

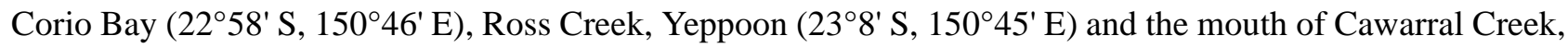
Keppel Sands (2319' S, 150 47' E) in Central Queensland, Australia. A total of 1766 N. dorsatus and 1908 N. olivaceus were collected between August 2004 and May 2006. Molluscs were held in filtered seawater at room temperature $\left(20-28^{\circ} \mathrm{C}\right)$ and examined for naturally emerged cercariae every 1-3 days for up to one month. Freshly emerged cercariae were transferred to a cavity block in a small volume of seawater and heatkilled by pouring several volumes of near boiling seawater into the dish. Specimens for morphological analysis were fixed in 5\% formalin and specimens for molecular analysis were stored in $70 \%$ ethanol or in phosphate buffered saline at $-20^{\circ} \mathrm{C}$. One or more infected molluscs were dissected to determine the nature of intra-molluscan stages for each cercarial species. Rediae were placed into near boiling seawater and fixed in $5 \%$ formalin or $70 \%$ ethanol. Representative wholemounts were stained with Mayer's haematoxylin, dehydrated through a graded series of ethanol, cleared in methyl salicylate and mounted in Canada balsam. Wholemounts and wet specimens are deposited in the Queensland Museum, Brisbane, Queensland, Australia.

Morphological analysis. Fixed cercariae were examined as temporary wet mounts without flattening. Live specimens and rediae were also observed as temporary wet mounts. Measurements were taken using an eyepiece micrometer on an Olympus BX-41 microscope and are given in micrometres as the range followed by the mean in parentheses. Standard deviations were calculated where more than 30 measurements were taken. Drawings were prepared with the aid of a drawing tube. Line drawings of $C$. capricornia VII and $C$. capricornia VIII were deposited in MorphBank (http://www.morphbank.net/).

Confirmation of prevalence. Of 17 infections, mature cercariae for morphological analysis were not available from one $N$. olivaceus and this specimen was omitted from the calculation of prevalence. A subset of putatively uninfected molluscs was dissected to confirm the absence of infection. Of $556 \mathrm{~N}$. dorsatus (31.5\% of 1766) and $399 \mathrm{~N}$. olivaceus (20.9\% of 1908) dissected, there were just two $N$. dorsatus infected with a trematode similar to those described here, but the cercariae were too immature for morphological comparison. This result suggests that the emergence prevalence reported here closely approximates the actual prevalence.

Molecular analysis. Total genomic DNA was extracted from fresh, frozen or alcohol fixed specimens using a QIAGEN ${ }^{\circledR}$ DNeasy ${ }^{\circledR}$ Blood and Tissue Kit following the manufacturer's protocol, except that the incubation step with Proteinase $\mathrm{K}$ was extended to overnight in a rotating incubator at $56^{\circ} \mathrm{C}$. Final elution 
volume was 30-200 $\mu \mathrm{L}$. Amplification of the partial LSU rDNA region was performed with the primers LSU 5 (5' -TAGGTCGACCCGCTGAAYTTAAGCA-3' Littlewood et al. 2000) and ECD2 (5'CCTTGGTCCGTGTTTCAAGACGGG-3' Littlewood et al. 2000) and the ITS2 region with the primers 3S (5'-GGTACCGGTGGATCACGTGGCTAGTG-3' Morgan \& Blair 1995) and ITS2.2 (5' CCTGGTTAGTTTCTTTTCCTCCGC-3' Cribb et al. 1998). PCR amplification (total volume $50 \mu \mathrm{L}$ ) was performed using 1X iTaq Buffer (Bio-Rad), $1.25 \mathrm{U}_{\text {iTaq }}{ }^{\mathrm{TM}}$ DNA polymerase (Bio-Rad), $1.5 \mathrm{mM} \mathrm{MgCl}, 200$ $\mu \mathrm{M}$ each dNTP, $0.2 \mu \mathrm{M}$ each primer and 1-10 $\mu \mathrm{L}$ genomic extract, with the following thermocycling profile: 5 min denaturation at $95^{\circ} \mathrm{C} ; 30$ cycles of $30 \mathrm{~s}$ at $95^{\circ} \mathrm{C}, 30 \mathrm{~s}$ at $60^{\circ} \mathrm{C}, 30 \mathrm{~s}$ at $72^{\circ} \mathrm{C}$; and 4 min extension at $72^{\circ} \mathrm{C}$. PCR amplicons were purified using a QIAGEN QIAquick ${ }^{\circledR}$ PCR Purification Kit (with $30 \mu$ L elution buffer). Purified amplicons were sequenced (in both directions) using the same primers with ABI BigDye ${ }^{\mathrm{TM}} \mathrm{v} 3.1$ chemistry at the Australian Genome Research Facility in Brisbane, Queensland. The resulting sequences were edited by eye and contigs constructed using Sequencher ${ }^{\mathrm{TM}}$ version 4.5 (GeneCodes Corp.). The sequences for each cercarial type were constructed from multiple replicates (each replicate contig being both a forward and reverse sequence from a single individual) from different host/locality combinations whenever possible.

Phylogenetic analyses. The partial LSU rDNA sequences for $C$. capricornia VII and $C$. capricornia VIII were aligned with data reported for the species of Acanthocolpidae and Brachycladiidae listed in Table 1. Species of Brachycladiidae were included as this family is considered closely related to the Acanthocolpidae (Bray et al. 2005). Cableia pudica Bray, Cribb \& Barker, 1996 was omitted from this analysis as recent molecular phylogenetic analyses have indicated that this species is a member of the Monorchiidae (Bray et al. 2005). Paragonimus westermani (Kerbert, 1878) and Paragonimus iloktsuenensis Chen, 1940 were chosen as outgroup taxa.

The partial LSU rDNA dataset was initially aligned using ClustalX version 2.0.9 (Larkin et al. 2007) under the following parameters: pairwise alignment parameters $=$ gap opening 10.00, gap extension 0.10 , DNA weight matrix International Union of Biochemistry (IUB); and multiple alignment parameters $=$ gap opening 10.00, gap extension 0.20 , delay divergent sequences $30 \%$, DNA weight matrix IUB. The resulting sequence alignment was exported from ClustalX in FASTA and NEXUS formats, and refined by eye using MacClade version 4.08 (Maddison \& Maddison 2005). After alignment of the LSU dataset was edited, the ends of each fragment were trimmed to match the shortest sequence in the alignment. Bayesian inference analysis of the LSU dataset was performed using MrBayes version 3.1.2 (Ronquist \& Huelsenbeck 2003) to explore relationships between these taxa. Modeltest version 3.7 (Posada \& Crandall 1998) was used to estimate the best substitution model for the LSU dataset. Bayesian inference analysis was conducted on the combined dataset using the $\mathrm{GTR}+\mathrm{I}+\mathrm{G}$ model predicted as the best estimator by the Akaike Information Criterion (AIC) in Modeltest. Bayesian inference analysis was run over 1,000,000 generations (ngen=1000000) with two runs each containing four simultaneous Markov Chain Monte Carlo (MCMC) chains (nchains=4) and every 100th tree saved (samplefreq=100). Bayesian analysis used the following parameters: $n s t=6$, rates=invgamma, ngammacat $=4$, and the MCMC parameters were left at the default settings, and the priors parameters of the combined dataset were set to ratepr=variable. Samples of substitution model parameters, and tree and branch lengths were summarised using the parameters 'sump burnin $=3000$ ' and 'sumt burnin $=3000$ '. These 'burnin' parameters were chosen because the log likelihood scores 'plateaued' well before 300,000 replicates in the Bayesian inference analysis.

ITS2 rDNA secondary structure prediction. The secondary structure of the ITS2 rDNA region for $C$. capricornia VII and C. capricornia VIII was predicted using minimum free energy folding algorithms with Mfold software version 3.2 (Zuker 2003). The ITS2 sequence was treated as linear and the folding temperature set at $37^{\circ} \mathrm{C}$ for analysis using Mfold. Alignment of the predicted ITS2 secondary structures for these two cercariae was performed using 4SALE (Seibel et al. 2008). Compensatory base change (CBC) analysis was then conducted on the aligned secondary structures using CBCAnalyzer software (Wolf et al. 2005). The predicted folding results from the Mfold analyses were viewed with Pseudoviewer version 3 (Byun \& Han 2006). 
TABLE 1. List of taxa and partial LSU rDNA sequences from GenBank used in this study.

\begin{tabular}{|c|c|c|}
\hline Species & Source: host/locality & GenBank accession \\
\hline \multicolumn{3}{|l|}{ Acanthocolpidae } \\
\hline Cercaria capricornia $\mathrm{VII}$ & Nassarius dorsatus, Capricornia, Australia & FJ809037 \\
\hline Cercaria capricornia VIII & Nassarius dorsatus, Capricornia, Australia & FJ809036 \\
\hline Monostephanostomum nolani Bray \& Cribb, 2007 & Carangoides plagiotaenia, Lizard Island, Australia & EF506763 \\
\hline Pleorchis polyorchis (Stossich, 1889) & Sciaena umbra, Scandola, Corsica & DQ248215 \\
\hline Pleorchis uku Yamaguti, 1970 & Aprion virescens, Lizard Island, Australia & DQ248216 \\
\hline $\begin{array}{l}\text { Stephanostomum adlardi Bray, Cribb, Waeschenbach \& } \\
\text { Littlewood, } 2007\end{array}$ & Plectropomus leopardus, Lizard Island, Australia & EF506761 \\
\hline Stephanostomum baccatum (Nicoll, 1907) & Hippoglossus hippoglossus, North Sea, UK & DQ248218 \\
\hline Stephanostomum baccatum (Nicoll, 1907) & Eutrigla gurnadus, North Sea, UK & AY222256 \\
\hline Stephanostomum bicoronatum (Stossich, 1883) & Sciaena umbra, Scandola, Corsica & DQ248225 \\
\hline Stephanostomum cesticillus (Molin, 1858) & Lophius piscatorius, Scandola, Corsica & DQ248226 \\
\hline Stephanostomum gaidropsari Bartoli \& Cribb, 2001 & Gaidropsarus mediterraneus, Marseille, France & DQ248221 \\
\hline Stephanostomum interruptum Sparks \& Thatcher, 1958 & Menticirrhus americanus, Gulf of Mexico, USA & DQ248223 \\
\hline Stephanostomum minutum (Looss, 1901) & Uranoscopus scaber, Scandola, Corsica & DQ248224 \\
\hline Stephanostomum pristis (Deslongchamps, 1824) & Phycis phycis, Scandola, Corsica & DQ248222 \\
\hline Stephanostomum tantabiddii Bray \& Cribb, 2004 & Carangoides fulvoguttatus, Ningaloo, Australia & DQ248220 \\
\hline Stephanostomum cf. $u k u$ Yamaguti, 1970 & Aprion virescens, Lizard Island, Australia & DQ248219 \\
\hline Tormopsolus orientalis (Yamaguti, 1934) & Seriola dumerili, Scandola, Corsica & DQ248217 \\
\hline \multicolumn{3}{|l|}{ Brachycladiidae } \\
\hline Zalophotrema hepaticum Stunkard \& Alvey, 1929 & Zalophus californianus, California, USA & AY222255 \\
\hline \multicolumn{3}{|l|}{ Paragonimidae } \\
\hline Paragonimus iloktsuenensis Chen, 1940 & Rattus norvegicus, Amami Island, Japan & AY116875 \\
\hline Paragonimus westermani (Kerbert, 1878) & Canis familiaris, Hyogo, Japan & AY116874 \\
\hline
\end{tabular}

\section{Results}

Two different types of acanthocolpid cercariae with morphology similar to described Stephanostomum cercariae emerged naturally from $N$. dorsatus and N. olivaceus.

\section{Morphological data - intramolluscan stages}

Diagnosis: Distomate cercariae. Dorsoventrally flattened body, longer than wide. Tegument spinose. Eyespots present. Oral sucker ventrally subterminal. Excretory vesicle Y-shaped. Tail simple, lacking spines, chaetae or fins. 


\section{Cercaria capricornia VII}

(Fig. 1)

Host: Nassarius dorsatus (Röding), (Gastropoda, Nassariidae).

Other host: Nassarius olivaceus (Bruguière), (Gastropoda, Nassariidae).

Locality: Cawarral Creek, Keppel Sands, Queensland (23ำ $19^{\prime}$ S; $150^{\circ} 47^{\prime}$ E).

Habitat: Intertidal mudflats.
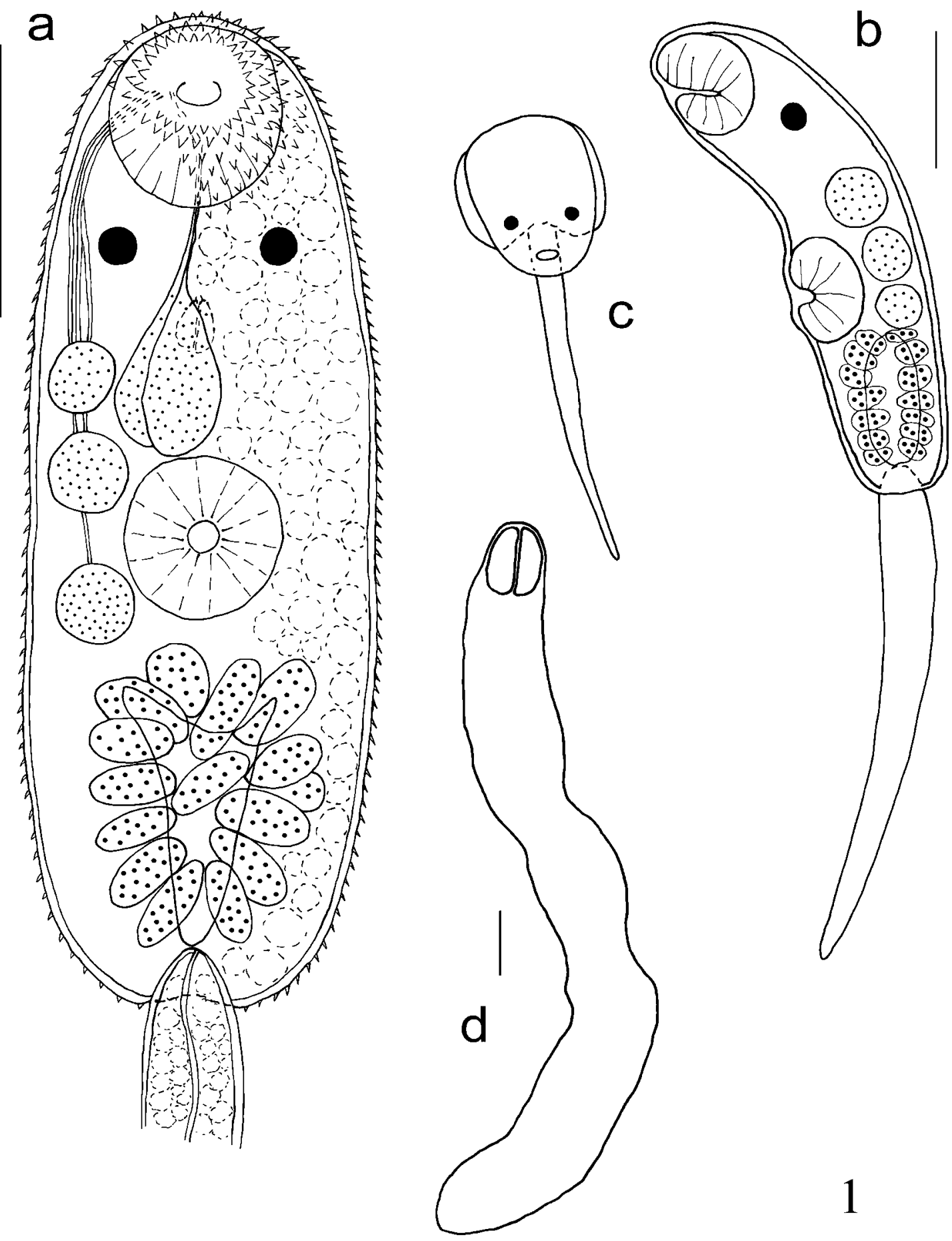

FIGURE 1. a-d. Cercaria capricornia VII, naturally emerged from Nassarius dorsatus and N. olivaceus. a. Body, heatkilled, in ventral view; b. Entire cercaria, heat-killed, from side view; c. Live cercaria, body folded for swimming, from ventral view; d. Redia, fixed. Scale bars a, b, $d=50 \mu \mathrm{m}$; c not to scale. 
TABLE 2. Morphometric comparison between Cercariae capricornia VII and VIII and published Stephanostomum and Stephanostomum-like cercariae (Gnana Mani 1994; Køie 1978; Madhavi \& Shameem 1993; Martin 1939; Stunkard 1961; Wolfgang 1955).

\begin{tabular}{|c|c|c|c|c|c|c|c|c|}
\hline & \multicolumn{2}{|c|}{ C. capricornia } & \multirow[t]{2}{*}{ S. dentatum } & \multirow[t]{2}{*}{ S. tenue } & \multirow[t]{2}{*}{ S. caducum } & \multirow[t]{2}{*}{ S. cloacum } & \multirow[t]{2}{*}{ S. baccatum } & \multirow{2}{*}{$\begin{array}{l}\text { C. bengalensis } \\
\text { VII }\end{array}$} \\
\hline & VII & VIII & & & & & & \\
\hline $\begin{array}{l}\text { Total body } \\
\text { length }\end{array}$ & $\begin{array}{l}155-250 \\
(195.2)\end{array}$ & $\begin{array}{l}182-240 \\
(205.3)\end{array}$ & $135-145$ & $\begin{array}{l}145-380 \\
(240)\end{array}$ & $\begin{array}{l}220-260 \\
(240)\end{array}$ & $480-500$ & $320-500$ & $\begin{array}{l}160-195 \\
(181)\end{array}$ \\
\hline $\begin{array}{l}\text { Maximumbody } \\
\text { width }\end{array}$ & $\begin{array}{l}50-85 \\
(69.2)\end{array}$ & $\begin{array}{l}62-83 \\
(70.5)\end{array}$ & $46-53$ & $\begin{array}{l}45-86 \\
(64)\end{array}$ & $\begin{array}{l}115-140 \\
(125)\end{array}$ & $154-166$ & $90-140$ & $\begin{array}{l}59-74 \\
(62)\end{array}$ \\
\hline $\begin{array}{l}\text { Forebody } \\
\text { length }\end{array}$ & $\begin{array}{l}75-125 \\
(97.2)\end{array}$ & $\begin{array}{l}95-138 \\
(112.4)\end{array}$ & & & & & & \\
\hline Tail length & $\begin{array}{l}142-210 \\
(175.6)\end{array}$ & $\begin{array}{l}215-270 \\
(253.6)\end{array}$ & $220-240$ & 183 & $250-300$ & $300-320$ & $540-640$ & $\begin{array}{l}210-244 \\
(194)\end{array}$ \\
\hline Tail width & $\begin{array}{l}17-28 \\
(20.6)\end{array}$ & $\begin{array}{l}20-30 \\
(22.1)\end{array}$ & $16-20$ & 31 & $25-35$ & $28-32$ & & $\begin{array}{l}20-23 \\
(20)\end{array}$ \\
\hline $\begin{array}{l}\text { Oral sucker } \\
\text { length }\end{array}$ & $\begin{array}{l}30-40 \\
(34.4)\end{array}$ & $\begin{array}{l}35-43 \\
(38.2)\end{array}$ & $24-25$ & 31 & $\begin{array}{l}42-50 \\
(48)\end{array}$ & $72-78$ & $60-80$ & $31-35$ \\
\hline $\begin{array}{l}\text { Oral sucker } \\
\text { width }\end{array}$ & $\begin{array}{l}27-38 \\
(33.4)\end{array}$ & $\begin{array}{l}32-38 \\
(35.4)\end{array}$ & $24-25$ & 30 & & $72-78$ & $60-80$ & $31-35$ \\
\hline $\begin{array}{l}\text { Ventral sucker } \\
\text { length }\end{array}$ & $\begin{array}{l}17-33 \\
(29.1)\end{array}$ & $\begin{array}{l}27-35 \\
(30.6)\end{array}$ & $23-24$ & 33 & $\begin{array}{l}35-38 \\
(37)\end{array}$ & 62 & $50-70$ & $31-35$ \\
\hline $\begin{array}{l}\text { Ventral sucker } \\
\text { width }\end{array}$ & $\begin{array}{l}20-35 \\
(30.4)\end{array}$ & $\begin{array}{l}27-35 \\
(31.3)\end{array}$ & $23-24$ & 30 & $\begin{array}{l}35-40 \\
(38)\end{array}$ & 66 & $50-70$ & $31-35$ \\
\hline Pharynx length & 10 & & $25-48$ & $25-52$ & 15 & $40-44$ & & $31-34$ \\
\hline $\begin{array}{l}\text { Excretory } \\
\text { vesicle length }\end{array}$ & $\begin{array}{l}37-75 \\
(52.1)\end{array}$ & $\begin{array}{l}42-55 \\
(49.7)\end{array}$ & & & & $88-100$ & & \\
\hline $\begin{array}{l}\text { Excretory } \\
\text { vesicle width }\end{array}$ & $\begin{array}{l}32-58 \\
(45.1)\end{array}$ & $\begin{array}{l}32-48 \\
(39.3)\end{array}$ & & & & $58-70$ & & \\
\hline Eyes & $\begin{array}{l}7-10 \\
\text { (diam.) }\end{array}$ & $\begin{array}{l}13 \times 10- \\
13\end{array}$ & $\begin{array}{l}9-12 \\
\text { (diam.) }\end{array}$ & & & & & $\begin{array}{l}8 \\
\text { (diam.) }\end{array}$ \\
\hline $\begin{array}{l}\text { Glands (central } \\
+ \text { lateral) }\end{array}$ & $2+3$ & $2+3$ & $2+3$ & $2+2$ & $2+3$ & $2+2$ & $2+0$ & $5+5$ \\
\hline $\begin{array}{l}\text { Oral sucker- } \\
\text { eye distance }\end{array}$ & $\begin{array}{l}32-55 \\
(46.6)\end{array}$ & $\begin{array}{l}37-68 \\
(53.6)\end{array}$ & & & & & & \\
\hline $\begin{array}{l}\text { Eye-eye } \\
\text { distance }\end{array}$ & $\begin{array}{l}12-28 \\
(20.3)\end{array}$ & $\begin{array}{l}7-23 \\
(14.4)\end{array}$ & & & & & & \\
\hline Stylet (length) & no & no & no & yes (12) & yes $(6)$ & yes & no & yes (5) \\
\hline
\end{tabular}

Other locality: Sandy Point, Corio Bay $\left(22^{\circ} 58^{\prime} \mathrm{S}, 150^{\circ} 46^{\prime} \mathrm{E}\right)$, Ross Creek, Yeppoon, Queensland $\left(23^{\circ} 8^{\prime}\right.$ $\left.\mathrm{S}, 150^{\circ} 45^{\prime} \mathrm{E}\right)$.

Location in host (redia): Digestive gland, gonads.

Prevalence of emergence: $0.57 \%$ ( 10 of $1766 \mathrm{~N}$. dorsatus), $0.21 \%$ (4 of $1908 \mathrm{~N}$. olivaceus).

Material deposited: Queensland Museum; G231698-G231720.

Molecular sequence data: ITS2, 6 replicates; LSU, 6 replicates.

GenBank accession numbers: ITS2 (FJ809039); LSU (FJ809037).

MorphBank accession number: 515656.

Dates of collection: August/November 2004, February/May-June/November 2005 and March/May 2006.

Description: Redia. (Fig. 1d, based on 10 unflattened specimens): Body elongate, cylindrical with posterior extremity tapering, 530-1210 (703.0) long by 60-120 (75.5) wide. Mouth opens terminally. Pharynx 25-32.5 (29.3) long by 20-25 (23.8) wide. In reproductive and digestive glands. 
Cercaria. (Figs 1a-c, based on 140 naturally emerged specimens): Body elliptical, longer than wide, widest point posterior to ventral sucker, 155-250 (195.2 \pm 16.1$)$ long by 50-85 (69.2 \pm 5.9$)$ wide; length/ width 2.27-4.17 (2.84 \pm 0.3$)$. Tegument spinose; spines arranged in regular rows. Tail simple, long, cylindrical, gradually tapering terminally, lacking spines, chaetae, fins, 142-210 (175.6 \pm 15.2$)$ long by 17-28 $(20.6 \pm 2.1)$ wide. Oral sucker 30-40 (34.4 \pm 2.2$)$ long by 27-38 (33.4 \pm 2.0$)$ wide. Ventral sucker 17-33 (29.1 $\pm 2.2)$ long by 20-35 (30.4 \pm 1.9$)$ wide. Mouth subterminal, opening anteroventrally, surrounded by spines; spines around mouth aperture slightly larger than on surrounding tegument. Forebody 75-125 (97.2 \pm 8.9) long; forebody/hindbody $0.80-1.34(0.99 \pm 0.07)$. Pharynx generally obscured by central glands, pyriform, 10 long by 12 wide $(n=1)$. Penetration glands in 5 pairs; 2 pairs median and immediately anterior to ventral sucker and 3 pairs lateral or anterolateral to ventral sucker. Excretory vesicle 37-75 (52.1 \pm 6.1$)$ long by $32-$ $58(45.1 \pm 4.7)$ wide; V-shaped when full, Y-shaped when empty; excretory duct appears to continue length of tail. Eye-spots dense, spherical, 12-28 (20.3 \pm 2.9$)$ apart, 32-55 (46.6 \pm 5.0$)$ from anterior end; 7-10 diameter $(n=24)$.

Remarks: Large numbers of cercariae emerge, sometimes on consecutive days, with pauses between emergences (few days to weeks). Cercariae generally emerge before 8 am. Naturally emergent cercariae are free-swimming and strongly positively phototactic. When swimming, the hindbody is folded ventrally (Fig. 1c) and the tail lashes from side to side for movement. When resting, the hindbody remains folded ventrally. When first emerged, cercariae swim actively towards light, frequently forming swarms near the surface. After about 24 hours, cercariae become less active. Cercariae were never observed to encyst.

Cercaria capricornia VII can be distinguished from the cercariae of S. tenue, S. cloacum, S. caducum and C. bengalensis VII by the absence of a stylet (Gnana Mani 1994; Køie 1978; Madhavi \& Shameem 1993; Martin 1939). Stephanostomum baccatum is larger and has no lateral penetration glands (Wolfgang 1955). Stephanostomum dentatum has a tail with lateral cuticular fins and is photonegative (Stunkard 1961). Morphometric comparison between $C$. capricornia VII and $C$. capricornia VIII, S. tenue, S. cloacum, $S$. caducum, C. bengalensis VII, S. baccatum and S. dentatum is given in Table 2.

\section{Cercaria capricornia VIII}

(Fig. 2)

Host: Nassarius dorsatus (Röding) (Gastropoda, Nassariidae).

\section{Other host: None.}

Locality: Cawarral Creek, Keppel Sands, Queensland (2319' S; $\left.150^{\circ} 47^{\prime} \mathrm{E}\right)$.

Habitat: Intertidal mudflats.

Location in host (redia): Digestive gland, gonads.

Prevalence of emergence: $0.11 \%$ ( 2 of $1766 N$. dorsatus).

Material deposited: Queensland Museum; G231721-G231724.

Molecular sequence data: ITS2, 1 replicate; LSU, 1 replicate.

GenBank accession numbers: ITS2 (FJ809038); LSU (FJ809036).

MorphBank accession number: 515658.

Dates of collection: August and November 2004.

Description: Redia. (Fig. 2c, based on 10 unflattened specimens): Body elongate,

cylindrical with posterior extremity tapering, 240-580 (416.0) long by 35-50 (41.5) wide. Mouth opens terminally. Pharynx 27-30 (28.5) long by 20-25 (23.3) wide. In reproductive and digestive glands.

Cercaria. (Figs 2a-b, based on 30 naturally emerged specimens): Body elliptical, longer than wide, widest point anterior to ventral sucker, $182-240(205.3 \pm 13.1)$ long by $62-83(70.5 \pm 4.7)$ wide; length/width ratio 2.48-3.31 (2.92 \pm 1.2$)$. Tegument spinose; spines arranged in regular rows. Tail simple, long, cylindrical, gradually tapering terminally, lacking spines, chaetae, fins, 215-270 (253.6 \pm 13.4$)$ long by 20-30 (22.1 \pm 2.2$)$ wide. Oral sucker 35-43 (38.2 \pm 1.8$)$ long by 32-38 (35.4 \pm 1.9$)$ wide. Ventral sucker 27-35 (30.6 \pm 1.7$)$ long by $27-35(31.3 \pm 1.8)$ wide. Mouth subterminal, opening anteroventrally, surrounded by spines; spines around mouth aperture slightly larger than on surrounding tegument. Forebody 95-138 (112.4 \pm 9.8$)$ long; forebody/ 
hindbody ratio $1.08-1.34$ (1.21 \pm 0.07$)$. Pharynx obscured by central glands. Penetration glands in 5 pairs; 2 pairs median and immediately anterior to ventral sucker and 3 pairs lateral or anterolateral to ventral sucker. Excretory vesicle $42-55(49.7 \pm 2.8)$ long by $32-48(39.3 \pm 3.5)$ wide; V-shaped when full, Y-shaped when empty; excretory duct appears to continue length of tail. Eye-spots dense, oblong, 7-23 (14.4 \pm 2.9$)$ apart, 37 $68(53.6 \pm 6.1)$ from anterior end; 13 long by $10-13$ wide $(n=7)$.
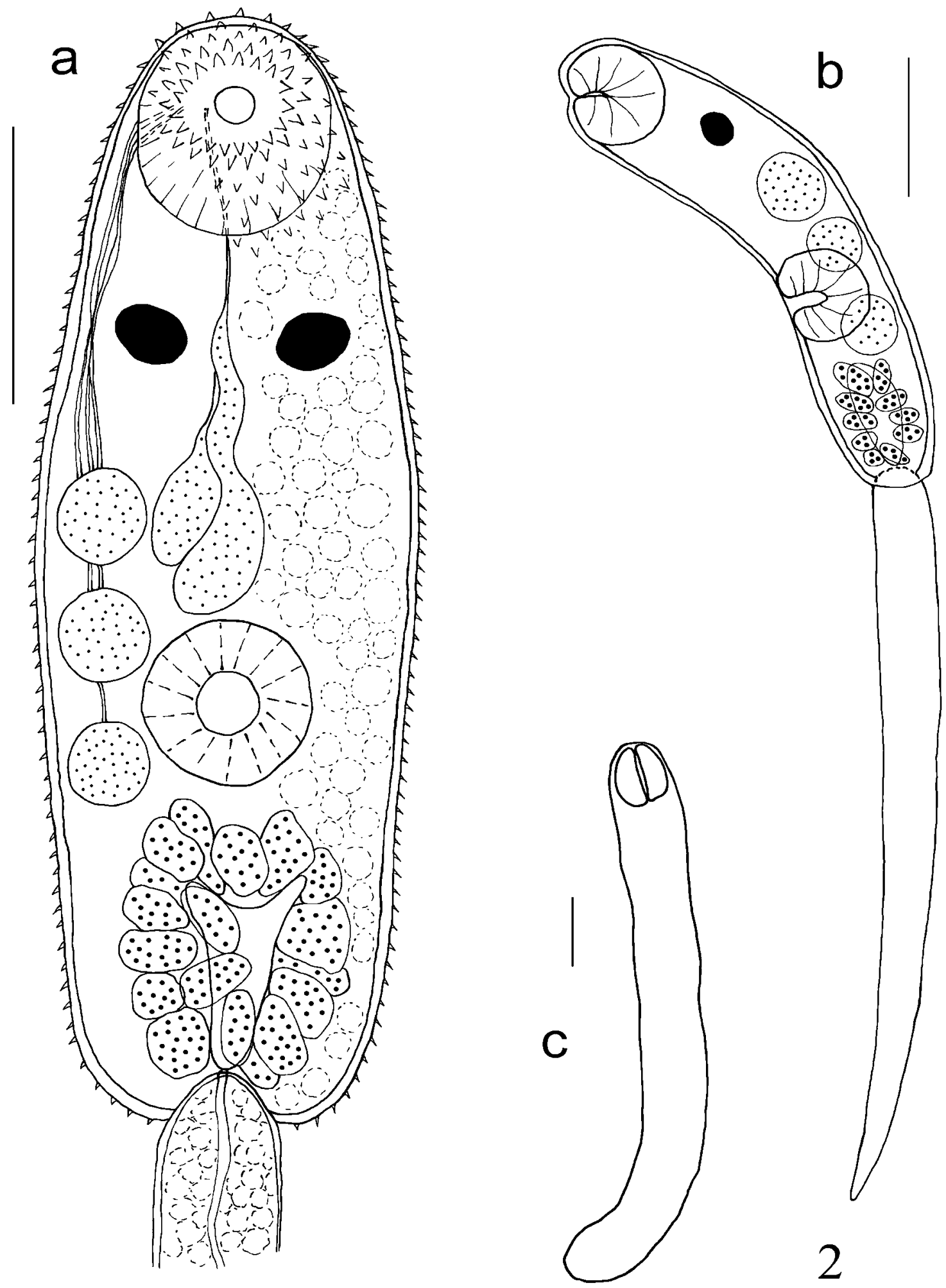

FIGURE 2. a-c. Cercaria capricornia VIII, naturally emerged from Nassarius dorsatus. a. Body, heat-killed, in ventral view; b. Entire cercaria, heat-killed, from side view; c. Redia, fixed. Scale bars a, b, c = $50 \mu \mathrm{m}$. 


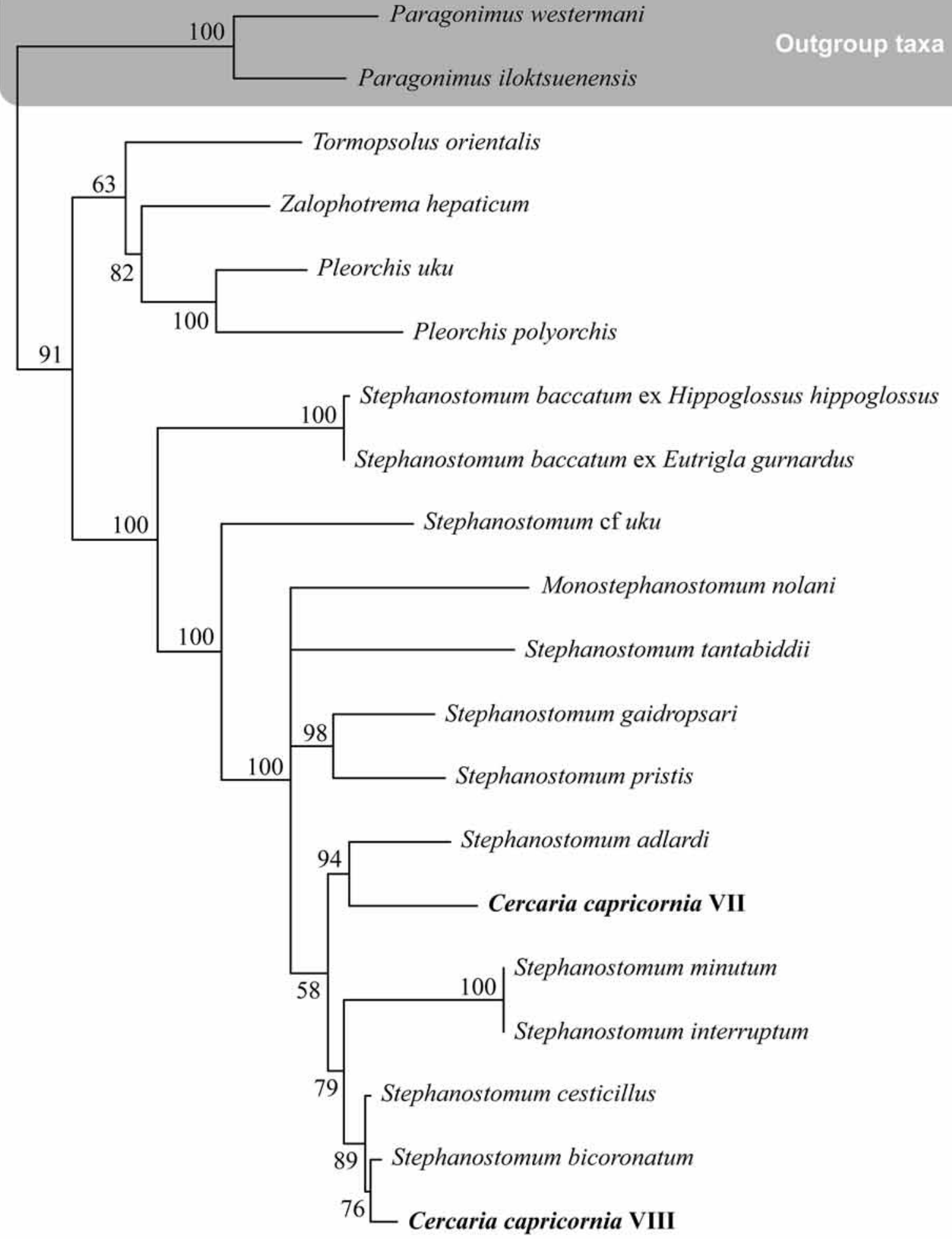

10 changes

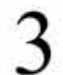

FIGURE 3. Relationships between Cercaria capricornia VII and $C$. capricornia VIII and the remainder of the taxa examined based on Bayesian inference analysis of partial LSU rDNA. Posterior probabilities are shown at the nodes with values $<50$ not shown. 


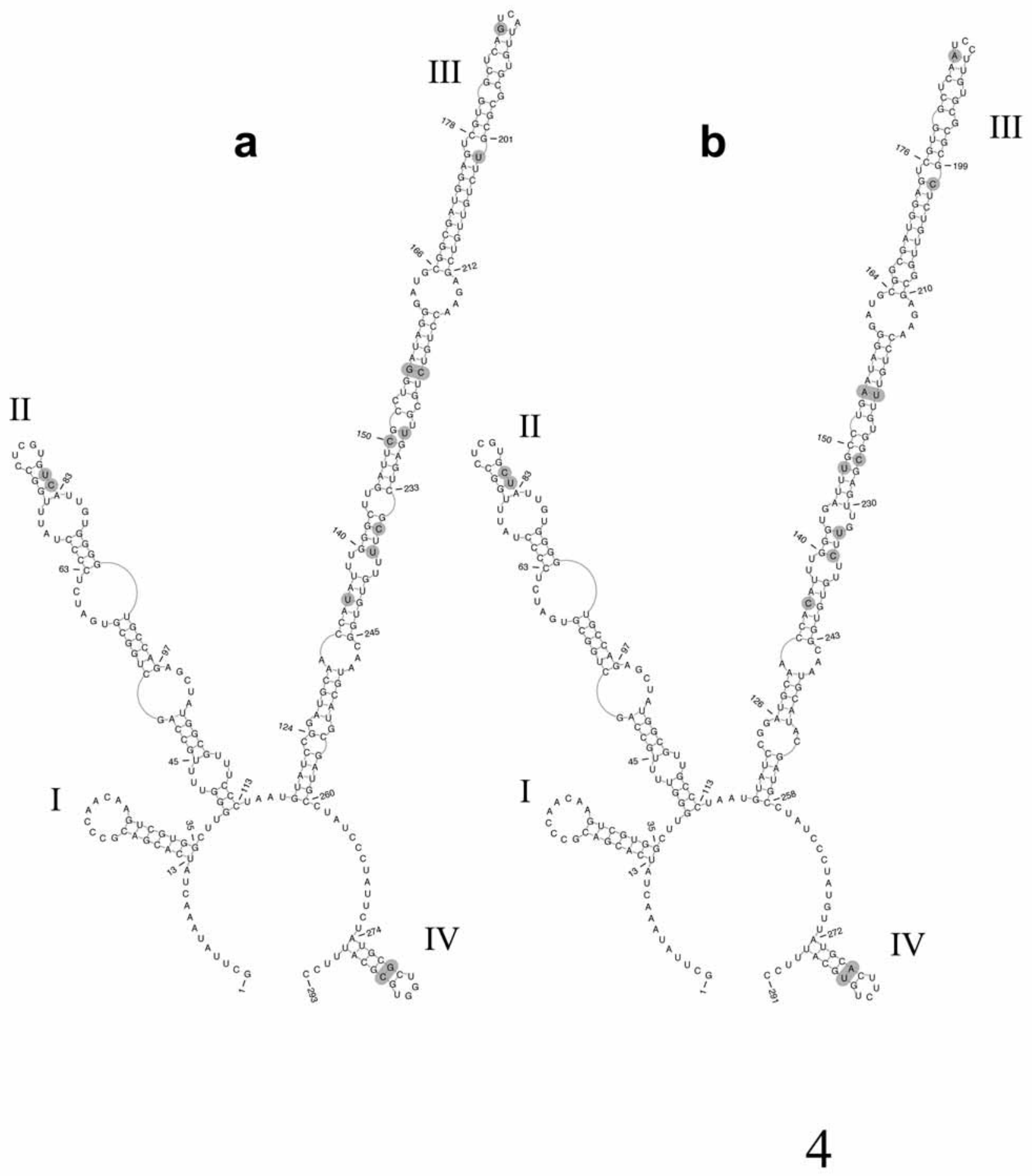

FIGURE 4. Inferred secondary structure of the ITS2 rDNA region for based on minimum free-energy modelling for $\mathbf{a}$. Cercaria capricornia VII and b. C. capricornia VIII. Helices one through four are indicated with Roman numerals. Complete compensatory base changes (CBCs) and hemi-CBCs are indicated in grey.

Remarks: Large numbers of cercariae emerge, sometimes on consecutive days, with pauses between emergences (few days to weeks). Cercariae generally emerge before 8 am. Naturally emergent cercariae are free-swimming and strongly positively phototactic. When swimming, the hindbody is folded ventrally and the tail lashes from side to side for movement, similar to $C$. capricornia VII (see Fig. 1c). When resting, the 
hindbody remains folded ventrally. When first emerged, cercariae swim actively towards light, frequently forming swarms near the surface. After about 24 hours, cercariae become less active. Cercariae were never observed to encyst.

Cercaria capricornia VIII can also be distinguished from S. tenue, S. cloacum, S. caducum and C. bengalensis VII by the absence of a stylet, from $S$. baccatum by size and the presence of lateral penetration glands, and from $S$. dentatum by the absence of lateral cuticular fins on the tail.

Cercaria capricornia VIII has a longer tail relative to body length than C. capricornia VII, and the eyespots are oblong in shape and larger than the spherical eye-spots of $C$. capricornia VII. The hindbody of $C$. capricornia VIII tapers inward towards the tail and the widest point of the body is anterior to the ventral sucker, while the hindbody of $C$. capricornia VII is broader with the widest point posterior to the ventral sucker. Morphometric comparison between C. capricornia VIII and C. capricornia VII, S. tenue, S. cloacum, S. caducum, C. bengalensis VII, S. baccatum and S. dentatum is given in Table 2.

\section{Molecular data}

Comparative LSU rDNA analysis: Alignment of the partial LSU rDNA region for $C$. capricornia VII and C. capricornia VIII and the remainder of the taxa examined yielded 884 characters for analysis. Neither cercaria showed any intraspecific variation over the LSU rDNA region sequenced here.

Bayesian inference analysis of the LSU dataset resulted in a phylogram with $C$. capricornia VII and $C$. capricornia VIII nested well within a clade containing species of Stephanostomum (Fig. 3). Cercaria capricornia VII formed a well-supported clade with Stephanostomum adlardi Bray, Cribb, Waeschenbach \& Littlewood, 2007, while C. capricornia VIII was observed as sister to Stephanostomum bicoronatum (Stossich, 1883) Fuhrmann, 1928. Most genera were well resolved with strong posterior probability support in the Bayesian inference analysis. The only exception was that Monostephanostomum nolani Bray \& Cribb, 2007 nested within the well-supported clade containing species of the Stephanostomum. The Acanthocolpidae was resolved here as paraphyletic, with the brachycladiid Zalophotrema hepaticum Stunkard \& Alvey, 1929 nested within a clade containing species of Tormopsolus Poche, 1926 and Pleorchis Railliet, 1896.

ITS2 rDNA sequencing and secondary structure prediction: The ITS2 rDNA regions sequenced for $C$. capricornia VII and C. capricornia VIII were 293 and 291 nucleotides long (respectively). No intraspecific variation was observed in this region for these cercarial types. The putative secondary structure predicted for the ITS2 region of $C$. capricornia VII using Mfold software resulted in a four helix model with a calculated free-energy minimum of $-108.2 \mathrm{kcal} / \mathrm{mol}$ (Fig. 4a). The putative ITS2 secondary structure predicted for $C$. capricornia VIII also resulted in a four helix model, which had a calculated free-energy minimum of -115.0 $\mathrm{kcal} / \mathrm{mol}$ (Fig. $4 \mathrm{~b}$ ). Helices I and IV of these putative models are both relatively short, each containing fewer than 25 nucleotides. Helix III in both secondary structure prediction models was the longest, comprising approximately 140 nucleotides.

Compensatory base change analysis for the two cercariae revealed the presence in each of two CBCs (one in Helix III and the other near the distal end of Helix IV) and nine hemi-CBCs (two near the distal end of Helix II and seven in Helix III) (Fig. 4).

\section{Discussion}

Systematics

The combined morphological and molecular data for C. capricornia VII and C. capricornia VIII suggest strongly that these are cercariae of species of Stephanostomum. These cercariae are morphologically similar to previously described acanthocolpid cercariae, but can be readily distinguished using morphometric data (Table 2).

Cercaria capricornia VII and C. capricornia VIII have a body shape similar to those of the cercariae of $S$. cloacum and $S$. baccatum, but are smaller and can also be differentiated from $S$. baccatum by molecular 
analysis (Fig. 3) and the number of penetration glands (Table 2). They are also similar in body shape to $C$. bengalensis VII, but in that cercaria the suckers were of equal size, whereas in $C$. capricornia VII and $C$. capricornia VIII the oral sucker is larger than the ventral sucker. They have a simple tail unlike $S$. dentatum which has a tail with lateral cuticular fins. The cercaria of $S$. tenue has a longer body, with an elongated hindbody compared to $C$. capricornia VII and C. capricornia VIII. The body of $S$. caducum is broader and with larger oral and ventral suckers. In addition, no stylet was seen in C. capricornia VII or C. capricornia VIII, while a stylet was reported for S. tenue, S. cloacum S. caducum and C. bengalensis VII.

TABLE 3. List of species of Acanthocolpidae reported from Australian and South Pacific waters and partial LSU rDNA sequences from GenBank.

\begin{tabular}{|c|c|c|}
\hline Species & Publication & $\begin{array}{l}\text { GenBank } \\
\text { accession }\end{array}$ \\
\hline \multicolumn{3}{|l|}{ Acanthocolpidae } \\
\hline Monostephanostomum nolani Bray \& Cribb, 2007 & (Bray \& Cribb 2007a) & EF506763 \\
\hline Monostephanostomum krusei Reimer, 1983 & (Bray \& Cribb 2007a) & \\
\hline Monostephanostomum georgianum Bray \& Cribb, 2002 & (Bray \& Cribb 2002) & \\
\hline Monostephanostomum manteri Kruse, 1979 & (Bray \& Cribb 2002) & \\
\hline Ningalooia psammopercae Bray \& Cribb, 2007 & (Bray \& Cribb 2007b) & \\
\hline Pleorchis uku Yamaguti, 1970 & (Bray et al. 2005) & DQ248216 \\
\hline Stephanostomum aaravi Bray \& Cribb, 2003 & (Bray \& Cribb 2003) & \\
\hline Stephanostomum adlardi Bray, Cribb, Waeschenbach \& Littlewood, 2007 & (Bray et al. 2007) & EF506761 \\
\hline Stephanostomum bicoronatum (Stossich, 1883) Fuhrmann, 1928 & (Bray \& Cribb 2003) & DQ248225 \\
\hline Stephanostomum carangi Liu, 1998 & (Bray \& Cribb 2008) & \\
\hline Stephanostomum cobia Bray \& Cribb, 2003 & (Bray \& Cribb 2003) & \\
\hline Stephanostomum ditrematis (Yamaguti, 1939) Manter, 1947 & (Bray \& Cribb 2008) & \\
\hline Stephanostomum hawaiiense Yamaguti, 1970 & (Bray \& Cribb 2008) & \\
\hline Stephanostomum lamothei Bray \& Cribb, 2008 & (Bray \& Cribb 2008) & \\
\hline Stephanostomum madhaviae Bray \& Cribb, 2003 & (Bray \& Cribb 2003) & \\
\hline Stephanostomum nуоoтwa Bray \& Cribb, 2003 & $\begin{array}{l}\text { (Bray \& Cribb 2003; Bray \& Cribb } \\
\text { 2008) }\end{array}$ & \\
\hline Stephanostomum pagrosomi (Yamaguti, 1939) Manter, 1947 & (Bray \& Cribb 2003) & \\
\hline Stephanostomum petimba Yamaguti, 1970 & $\begin{array}{l}\text { (Bray \& Cribb 2003; Hutson et al. } \\
\text { 2007) }\end{array}$ & \\
\hline Stephanostomum talakitok Bray \& Cribb, 2006 & (Bray \& Cribb 2006) & \\
\hline Stephanostomum tantabiddii Bray \& Cribb, 2004 & (Bray \& Cribb 2004) & DQ248220 \\
\hline Stephanostomum tupatupa Bray \& Cribb, 2008 & (Bray \& Cribb 2008) & \\
\hline Stephanostomum cf. uku Yamaguti, 1970 & (Bray et al. 2005) & DQ248219 \\
\hline Stephanostomum pacificum (Yamaguti, 1951) Yamaguti, 1953 & (Bray \& Cribb 2003) & \\
\hline Stephanostomum votonimoli Bray \& Cribb, 2003 & (Bray \& Cribb 2003) & \\
\hline Tormopsolus orientalis Yamaguti, 1934 & $\begin{array}{l}\text { (Bartoli et al. 2004; Hutson et al. } \\
\text { 2007) }\end{array}$ & DQ248217 \\
\hline Tormopsolus attenuatus Bray \& Cribb, 2001 & (Bray \& Cribb 2001) & \\
\hline Venusicola inusitatus Bray \& Cribb, 2000 & (Bray \& Cribb 2000) & \\
\hline
\end{tabular}

Cercariae capricornia I-VI, also reported from nassariid gastropods, have an expanded hindbody and an unusual body shape, including a keel, strikingly different to that of these cercariae.

Cercaria capricornia VII and C. capricornia VIII can also be differentiated from other acanthocolpid cercariae. Cercaria caribbea XXXIV Cable, 1956, Cercaria portosacculus Holliman, 1961, Cercaria caribbea LXXII Cable, 1963, and Cercaria caribbea LXXIII Cable, 1963, have unusual caudal features 
which differentiate them from C. capricornia VII and C. capricornia VIII (Cable 1956; Cable 1963; Holliman 1961), while Cercaria itoi Shimura, 1984 and a probable Tormopsolus cercaria described by Bartoli and Gibson have an expanded hindbody and are larger than C. capricornia VII and C. capricornia VIII (Bartoli \& Gibson 1998; Shimura 1984).

Neophasis anarrhichae (Nicoll, 1909) Bray, 1987 (syn. Neophasis lageniformis (Lebour, 1910) Miller, 1941) was reported with 7-8 pairs of glands, and was suggested to lose its tail whilst in the redia and not emerge from the snail (Chubrik 1966). The tail of Neophasis oculatus (Levinsen, 1881) Miller, 1941 is much longer and tegumental spines are restricted to the anterior end (Chubrik 1966). Another probable Neophasis cercaria from Neptunea despecta (Linnaeus), Neptunea borealis (Philippi) and Cryptonatica affinis (Gmelin) (syn. Cryptonatica [Tectonatica] clausa Broderip \& Sowerby) was spinose anterior to the eyes only and was larger than C. capricornia VII and C. capricornia VIII (Marasaev 1984).

Cercaria criollisima V Nasir, 1976, a cercaria suggested by Madhavi and Shameem (1993) to have characters which fit those of acanthocolpids, was described as having an anterior organ more as a penetration device than a sucker, while both $C$. capricornia VII and $C$. capricornia VIII have obvious oral suckers (Madhavi \& Shameem 1993; Nasir 1976). In addition, C. criollisima V was reported to develop in sporocysts, while $C$. capricornia VII and C. capricornia VIII develop in rediae.

The acanthocolpid fauna of fishes from Australian and South Pacific waters is rich (Table 3). There are presently four species of Monostephanostomum, one species of Ningalooia, one species of Pleorchis, 18 species of Stephanostomum, two species of Tormopsolus and one species of Venusicola known. Species of Stephanostomum reported from eastern Australian waters include S. adlardi, S. aaravi, S. bicoronatum, S. carangi, S. cobia, S. ditrematis, S. hawaiiense, S. lamothei, S. madhaviae, S. nyoomwa, S. pagrosomi, $S$. petimba, S. talakitok, S. tantabiddii, S. tupatupa, and $S$. cf. uku. Of these, only $S$. adlardi, S. bicoronatum, $S$. tantabiddii and $S$. cf. $u k u$ have published partial LSU rDNA sequences available for comparison. Molecular analysis indicates that $C$. capricornia VII and $C$. capricornia VIII are not cercariae from these four species. Cercaria capricornia VII resolved as a sister to $S$. adlardi and C. capricornia VIII to S. bicoronatum, both species reported from fishes of eastern Australian waters.

\section{First intermediate hosts}

We are now aware of 25 apparently distinct cercariae that have been referred to the Acanthocolpidae, either definitively by experimental infection, by molecular phylogenetic analysis as here, or by shared general morphology. We find all these identifications broadly convincing except for $C$. criollisima $\mathrm{V}$, which, uniquely for this group, was reported from a bivalve (Veneridae) rather than a gastropod. There are nine families of trematodes that routinely infect bivalves as first intermediate hosts and a few others (e.g. Lepocreadiidae, Hemiuridae) that infect them exceptionally (e.g. Hassanine 2006; Wardle 1975). The combination of prominent eye-spots, absence of a stylet, simple tail and parasitism of a marine rather than a freshwater bivalve distinguish C. criollisima $\mathrm{V}$ from eight of these, the Allocreadiidae, Aporocotylidae, Bucephalidae, Faustulidae, Fellodistomidae, Gorgoderidae, Gymnophallidae and Tandanicolidae. The morphology of $C$. criollisima $\mathrm{V}$ is broadly consistent with the cercariae of some Monorchiidae in which the tail is welldeveloped such as C. caribbea XXXV Cable, 1956, C. caribbea LXIII Cable, 1963 and that of Paratimonia gobii Prevot \& Bartoli, 1967 (Cable 1956; Cable 1963; Maillard 1975). We will therefore not consider this cercaria further as a possible acanthocolpid.

If $C$. criollisima $\mathrm{V}$ is excluded, then all the other putative acanthocolpid cercariae develop in gastropods (Table 4). All infections are in the Clade Hypsogastropoda (Bouchet \& Rocroi 2005) which incorporates numerous superfamilies of which just two, Buccinoidea and Naticoidea, are infected by putative acanthocolpids. Naticoidea has just one family, Naticidae, and this has been shown convincingly to harbour species of Neophasis and Stephanostomum (Chubrik 1966; Køie 1978; Marasaev 1984; Yamaguti 1975). Acanthocolpids are known from four families of Buccinoidea. Cribb et al. (2001) reviewed the overall pattern of specificity of trematodes in fishes and first intermediate hosts. They found that no well-studied taxon has a relatively narrower range of vertebrate definitive hosts than of molluscan intermediate hosts, but they did not consider the Acanthocolpidae in any detail. The present results suggest that this family is consistent with the 
TABLE 4. First intermediate hosts of putative Acanthocolpidae.

\begin{tabular}{|c|c|c|}
\hline Host species & Parasite species & Reference \\
\hline \multicolumn{3}{|l|}{ Superfamily Buccinoidea } \\
\hline \multicolumn{3}{|l|}{ Buccinidae } \\
\hline \multirow[t]{2}{*}{ Buccinum undatum Linnaeus } & $\begin{array}{l}\text { Neophasis anarrhichae (Nicoll, 1909) Bray, } 1987 \\
\text { syn. Neophasis lageniformis (Lebour, 1910) Miller, } 1941\end{array}$ & $\begin{array}{l}\text { (Chubrik 1966; Køie 1971; Køie } \\
\text { 1973) }\end{array}$ \\
\hline & $\begin{array}{l}\text { Stephanostomum baccatum (Nicoll, 1907) Manter, } 1934 \\
\text { syn. Cercaria neptunae Lebour, } 1911\end{array}$ & $\begin{array}{l}\text { (MacKenzie \& Liversidge 1975; } \\
\text { Wolfgang 1955; Yamaguti 1971; } \\
\text { Yamaguti 1975) }\end{array}$ \\
\hline Cantharus dorbignyi Payraudau & Tormopsolus sp. & (Bartoli \& Gibson 1998) \\
\hline Neptunea antiqua (Linnaeus) & $\begin{array}{l}\text { Stephanostomum baccatum (Nicoll, 1907) Manter, } 1934 \\
\text { syn. Cercaria neptunae Lebour, 1911 }\end{array}$ & (MacKenzie \& Liversidge 1975) \\
\hline Neptunea borealis (Philippi) & Neophasis sp. & (Marasaev 1984) \\
\hline $\begin{array}{l}\text { Neptunea decemcostata (Say) syn. } \\
\text { Neptunea decemcostatum (Say) }\end{array}$ & $\begin{array}{l}\text { Stephanostomum baccatum (Nicoll, 1907) Manter, } 1934 \\
\text { syn. Cercaria neptunae Lebour, } 1911\end{array}$ & $\begin{array}{l}\text { (Wolfgang 1955; Yamaguti 1971; } \\
\text { Yamaguti 1975) }\end{array}$ \\
\hline Neptunea despecta (Linnaeus) & Neophasis sp. & (Marasaev 1984) \\
\hline \multicolumn{3}{|l|}{ Columbellidae } \\
\hline \multirow[t]{2}{*}{ Anachis obesa C. B. Adams } & Cercaria caribbea LXXII Cable, 1963 & (Cable 1963) \\
\hline & Cercaria portosacculus Holliman, 1961 & (Holliman 1961) \\
\hline \multirow[t]{2}{*}{ Columbella mercatoria (Linnaeus) } & Cercaria caribbea LXXIII Cable, 1963 & (Cable 1963; Yamaguti 1975) \\
\hline & Cercaria caribbea XXXIV Cable, 1956 & (Cable 1956) \\
\hline \multicolumn{3}{|l|}{ Fasciolariidae } \\
\hline Fusinus perplexus A. Adams & Cercaria itoi Shimura, 1984 & (Shimura 1984) \\
\hline \multicolumn{3}{|l|}{ Nassariidae } \\
\hline \multirow[t]{4}{*}{ Nassarius dorsatus (Röding) } & Cercaria capricornia V Barnett, Smales \& Cribb, 2008 & (Barnett et al. 2008) \\
\hline & Cercaria capricornia VI Barnett, Smales \& Cribb, 2008 & (Barnett et al. 2008) \\
\hline & Cercaria capricornia $\mathrm{VII}$ & This study \\
\hline & Cercaria capricornia VIII & This study \\
\hline \multirow[t]{2}{*}{ Nassarius obsoletus, Say } & $\begin{array}{l}\text { Stephanostomum dentatum (Linton, 1900) Linton, } 1940 \\
\text { syn. Cercaria dipterocerca Miller \& Northup, } 1926\end{array}$ & $\begin{array}{l}\text { (Miller \& Northup 1926; } \\
\text { Stunkard 1961; Yamaguti 1971; } \\
\text { Yamaguti 1975) }\end{array}$ \\
\hline & Stephanostomum tenue (Linton, 1898) Linton, 1934 & $\begin{array}{l}\text { (Martin 1939; Yamaguti 1971; } \\
\text { Yamaguti 1975) }\end{array}$ \\
\hline \multirow[t]{5}{*}{ Nassarius olivaceus (Bruguière) } & Cercaria capricornia I Barnett, Smales \& Cribb, 2008 & (Barnett et al. 2008) \\
\hline & Cercaria capricornia II Barnett, Smales \& Cribb, 2008 & (Barnett et al. 2008) \\
\hline & Cercaria capricornia III Barnett, Smales \& Cribb, 2008 & (Barnett et al. 2008) \\
\hline & Cercaria capricornia IV Barnett, Smales \& Cribb, 2008 & (Barnett et al. 2008) \\
\hline & Cercaria capricornia $\mathrm{VII}$ & This study \\
\hline Nassarius orissaensis (Preston) & $\begin{array}{l}\text { Stephanostomum cloacum (Srivastava, 1938) Manter \& } \\
\text { Van Cleave, } 1951\end{array}$ & (Madhavi \& Shameem 1993) \\
\hline Nassarius stolatus (Gmelin) & Cercaria bengalensis VII Gnana Mani, 1994 & (Gnana Mani 1994) \\
\hline \multicolumn{3}{|l|}{ Superfamily Naticoidea } \\
\hline \multicolumn{3}{|l|}{ Naticidae } \\
\hline \multirow[t]{2}{*}{$\begin{array}{l}\text { Cryptonatica affinis (Gmelin) syn. } \\
\text { Cryptonatica }[\text { Tectonatica] clausa } \\
\text { Broderip \& Sowerby }\end{array}$} & Neophasis oculatus (Levinsen, 1881) Miller, 1941 & $\begin{array}{l}\text { (Bray \& Gibson 1991; Chubrik } \\
\text { 1966) }\end{array}$ \\
\hline & Neophasis sp. & (Marasaev 1984) \\
\hline $\begin{array}{l}\text { Euspira pulchella (Risso) } \\
\text { syn. Natica alderi (Forbes) }\end{array}$ & Stephanostomum caducum (Looss, 1901) Manter 1934 & (Køie 1978) \\
\hline
\end{tabular}


overall pattern. Our records suggest that acanthocolpids have been reported as sexual adults from 24 orders of fishes but as intra-molluscan stages from just two superfamilies. Of course future collecting may modify this pattern but overall it appears that acanthocolpids have a narrow range of first intermediate hosts. However, range is not so restricted as to suggest that cophyly has occurred at the species level. We suspect that the overall pattern of host-specificity for gastropods suggests that the Acanthocolpidae radiated in association with the Buccinoidea and have subsequently transferred, perhaps at least twice, into the Naticoidea. However, far more host-parasite records will need to be accumulated and far better knowledge of the phylogenetic relationships in the Acanthocolpidae are needed for these ideas to be more than speculative.

Cribb et al. (2002) observed that Stephanostomum was the second largest genus of trematodes of fishes (second to Phyllodistomum from urinary bladders). The success of this genus is evident from the huge range of fishes (over 70 families) that are infected as adults. The genus also appears to have low specificity for first intermediate hosts, having been identified (or inferred) from three families and two superfamilies of molluscs. Given the current size of the genus there are clearly many more intermediate hosts to be found and we predict that further families of Buccinoidea and perhaps of other Hypsogastropoda will prove to be infected.

Relationships between Cercariae capricornia VII and VIII and other acanthocolpid taxa

Phylogenetic analysis of the taxa examined here showed that $C$. capricornia VII and $C$. capricornia VIII were nested within a clade containing species of Stephanostomum, suggesting that these cercariae are species of this relatively large acanthocolpid genus. The results of our Bayesian inference analysis using partial LSU rDNA sequences agree broadly with the phylogenetic hypothesis of relationships among the Acanthocolpidae based on complete small subunit (SSU) and partial LSU rDNA sequence data reported by Bray et al. (2005, 2007). One of the distinct differences in topology observed between the phylograms reported by Bray et al. $(2005,2007)$ and here is the position of $Z$. hepaticum, which forms a clade with species of Pleorchis to the exclusion of Tormopsolus in our analysis rather than sister to these genera (Fig. 3).

Inferred secondary structure of the ITS2 rDNA region

The inferred secondary structure of the ITS2 rDNA region for $C$. capricornia VII and C. capricornia VIII using minimum free energy modelling agrees with the core four helix domain structure (with helix III being the longest) that has been recently identified as common to almost all eukaryote taxa (Coleman 2003; Coleman 2007; Schultz et al. 2005). The optimal secondary structures inferred here for these putative acanthocolpid cercariae also agree with the four domain model of the ITS2 rDNA region using minimum free energy folding algorithms reported for other digenean families (Morgan \& Blair 1998). All four of the helices in the models for these two cercariae are of similar length and structure to that of the general digenean structure reported by Morgan \& Blair (1998) and Miller \& Cribb (2009).

Differences of as little as a single compensatory base change in the secondary structure pairing of the ITS2 rDNA region has recently been shown to be strongly correlated with sexual incompatibility and, therefore, possibly indicative of distinct "biological species" (Coleman 2009; Müller et al. 2007; Wolf et al. 2005). When compared, the two putative acanthocolpid cercariae reported here had two CBCs and nine hemiCBCs, which correlates well with our conclusion that two distinct species are present in this system based on phylogenetic analysis of LSU rDNA and the results of morphometric analysis. While it is clear that incorporating analysis of the secondary structure of the ITS2 rDNA region as well as phylogenetic analysis of raw sequence data will help in resolving relationships among difficult or cryptic taxonomic groups within the Acanthocolpidae, more comparative ITS2 secondary structure data is needed to address how the numbers of CBCs and hemi-CBCs observed may correlate with distinct 'biological species' within this family and the Digenea as a whole. 


\section{Acknowledgments}

We wish to thank Philip Barton for assistance with field collection and observation of snails, and Stephen McKillup, Ruth McKillup, Mary-Anne Jones, Tony Vize and Haylee Weaver for assistance with field collections.

\section{References}

Barnett, L.J., Smales, L.R. \& Cribb, T.H. (2008) A complex of putative acanthocolpid cercariae (Digenea) from Nassarius olivaceus and N. dorsatus (Gastropoda: Nassariidae) in Central Queensland, Australia. Zootaxa, 1705, 21-39.

Bartoli, P., Bray, R.A. \& Montero, F.E. (2004) Tormopsolus orientalis Yamaguti, 1934 (Digenea: Acanthocolpidae) from Seriola dumerili (Risso) (Perciformes: Carangidae) in the western Mediterranean Sea. Systematic Parasitology, 57, 201-209.

Bartoli, P. \& Gibson, D.I. (1998) A new acanthocolpid cercaria (Digenea) from Cantharus dorbignyi (Prosobranchia) in the Western Mediterranean. Systematic Parasitology, 40, 175-184.

Bouchet, P. \& Rocroi, J.-P. (Eds) (2005) Classification and Nomenclator of Gastropod Families. Malacologia: International Journal of Malacology, 47, 1-397.

Bray, R.A. (2005). Family Acanthocolpidae Lühe, 1906. In: Jones, A., Bray, R.A. \& Gibson, D.I. (Eds.), Keys to the Trematoda, Volume 2, CABI Publishing, pp. 603-619.

Bray, R., Cribb, T., Waeschenbach, A. \& Littlewood, D. (2007) A new species of Stephanostomum Looss, 1899 (Digenea, Acanthocolpidae) with a bizarre oral sucker: S. adlardi sp. nov. from the common coral trout Plectropomus leopardus (Lacepède, 1802) (Perciformes, Serranidae) from Lizard Island, Great Barrier Reef. Acta Parasitologica, 52, 206-212.

Bray, R.A. \& Cribb, T.H. (2000) Venusicola inusitatus gen. n., sp. n. (Digenea, Acanthocolpidae) from the Venus tuskfish Choerodon venustus (De Vis) from the southern Great Barrier Reef. Acta Parasitologica, 45, 295-298.

Bray, R.A. \& Cribb, T.H. (2001) Tormopsolus attenuatus n. sp. (Digenea: Acanthocolpidae) from Seriola hippos (Perciformes: Carangidae), Western Australia, with some observations on the relationships in the genus. Systematic Parasitology, 50, 91-99.

Bray, R.A. \& Cribb, T.H. (2002) Monostephanostomum georgianum n. sp. (Digenea: Acanthocolpidae) from Arripis georgianus (Valenciennes) (Perciformes: Arripidae) off Kangaroo Island, South Australia, with comments on Monostephanostomum Kruse, 1979 and Stephanostomum Looss, 1899. Systematic Parasitology, 53, 61-68.

Bray, R.A. \& Cribb, T.H. (2003) Species of Stephanostomum Looss, 1899 (Digenea: Acanthocolpidae) from fishes of Australian and South Pacific waters, including five new species. Systematic Parasitology, 55, 159-197.

Bray, R.A. \& Cribb, T.H. (2004) Stephanostomum tantabiddii n. sp. (Digenea: Acanthocolpidae) from Carangoides fulvoguttatus (Forsskål, 1775) (Perciformes: Carangidae) from Ningaloo Reef, Western Australia. Zootaxa, 457, 18.

Bray, R.A. \& Cribb, T.H. (2006) Stephanostomum talakitok n. sp. (Digenea: Acanthocolpidae) from the golden trevalley, Gnathanodon speciosus (Perciformes: Carangidae), from Ningaloo Reef, Western Australia. Zootaxa, 1104, 59-68.

Bray, R.A. \& Cribb, T.H. (2007a) Monostephanostomum nolani sp. n. and M. krusei Reimer, 1983 (Digenea: Acanthocolpidae) from carangid fishes from coral reef waters off Australia. Folia Parasitologica, 54, 19-26.

Bray, R.A. \& Cribb, T.H. (2007b) Ningalooia psammopercae n. g., n. sp. (Digenea: Acanthocolpidae) from the Waigieu seaperch Psammoperca waigiensis (Cuvier) (Perciformes: Latidae) on the Ningaloo Reef, Western Australia. Systematic Parasitology, 66, 131-135.

Bray, R.A. \& Cribb, T.H. (2008) Stephanostomum spp. (Digenea: Acanthocolpidae) from scombrids and carangids (Perciformes) from the Great Barrier Reef, with the description of two new species. Revista Mexicana de Biodiversidad, 79, 49S-68S.

Bray, R.A. \& Gibson, D.I. (1991) The Acanthocolpidae (Digenea) of fishes from the north-east Atlantic: the status of Neophasis Stafford, 1904 (Digenea) and a study of North Atlantic forms. Systematic Parasitology, 19, 95-118.

Bray, R.A., Webster, B.L., Bartoli, P. \& Littlewood, D.T.J. (2005) Relationships within the Acanthocolpidae Lühe, 1906 and their place among the Digenea. Acta Parasitologica, 50, 281-291.

Byun, Y. \& Han, K. (2006) Pseudoviewer: web application and web service for visualizing RNA pseudoknots and secondary structures. Nucleic Acids Research, 34, W416-W422.

Cable, R.M. (1956) Marine cercariae of Puerto Rico. Scientific Survey of Porto Rico and the Virgin Islands, 16, 491-577.

Cable, R.M. (1963) Marine cercariae from Curaçao and Jamaica. Zeitschrift für Parasitenkunde, 23, 429-469.

Chubrik, G.K. (1966) Fauna and ecology of trematode larvae from molluscs in the Barents and White Seas. Trudy 
Murmanskii Biologicheskii Institut, 10, 78-166.

Coleman, A.W. (2003) ITS2 is a double-edged tool for eukaryote evolutionary comparisons. Trends in Genetics, 19, 370-375.

Coleman, A.W. (2007) Pan-eukaryote ITS2 homologies revealed by RNA secondary structures. Nucleic Acids Research, $35,3322-3329$.

Coleman, A.W. (2009) Is there a molecular key to the level of "biological species" in eukaryotes? A DNA guide. Molecular Phylogenetics and Evolution, 50, 197-203.

Cribb, T.H., Anderson, G.R., Adlard, R.D. \& Bray, R.A. (1998) A DNA-based demonstration of a three-host life-cycle for the Bivesiculidae (Platyhelminthes: Digenea). International Journal for Parasitology, 28, 1791-1795.

Cribb, T.H., Bray, R.A. \& Littlewood, D.T.J. (2001) The nature and evolution of the association between digeneans, molluscs and fishes. International Journal for Parasitology, 31, 997-1011.

Cribb, T.H., Chisholm, L.A. \& Bray, R.A. (2002) Diversity in the Monogenea and Digenea: does lifestyle matter? International Journal for Parasitology, 32, 321-328.

Gnana Mani, G. (1994) Studies on Indian marine cercariae: a new acanthocolpid cercaria. Indian Journal of Parasitology, 18, 75-78.

Hassanine, R.M.E. (2006) The life cycle of Diploproctodaeum arothroni Bray and Nahhas, 1998 (Digenea: Lepocreadiidae), with a comment on the parasitic castration of its molluscan intermediate host. Journal of Natural History, 40, 1211-1222.

Holliman, R.B. (1961) Larval trematodes from the Apalachee Bay Area, Florida, with a checklist of known marine cercariae arranged in a key to their superfamilies. Tulane Studies in Zoology and Botany, 9, 1-74.

Hutson, K.S., Ernst, I., Mooney, A.J. \& Whittington, I.D. (2007) Metazoan parasite assemblages of wild Seriola lalandi (Carangidae) from eastern and southern Australia. Parasitology International, 56, 95-105.

Køie, M. (1971) On the histochemistry and ultrastructure of the redia of Neophasis lageniformis (Lebour, 1910) (Trematoda, Acanthocolpidae). Ophelia, 9, 113-143.

Køie, M. (1973) The ultrastructure of the caecal epithelium of the intraredial cercaria of Neophasis lageniformis (Lebour, 1910) (Trematoda, Acanthocolpidae). Cell and Tissue Research, 139, 405-416.

Køie, M. (1978) On the morphology and life-history of Stephanostomum caducum (Looss 1901) Manter 1934 (Trematoda, Acanthocolpidae). Ophelia, 17, 121-133.

Larkin, M.A., Blackshields, G., Brown, N.P., Chenna, R., McGettigan, P.A., McWilliam, H., Valentin, F., Wallace, I.M., Wilm, A., Lopez, R., Thompson, J.D., Gibson, T.J. \& Higgins, D.G. (2007) Clustal W and Clustal X version 2.0. Bioinformatics, 23, 2947-2948.

Littlewood, D.T., Curini-Galletti, M. \& Herniou, E.A. (2000) The interrelationships of Proseriata (Platyhelminthes: Seriata) tested with molecules and morphology. Molecular Phylogenetics and Evolution, 16, 449-466.

MacKenzie, K. \& Liversidge, J.M. (1975) Some aspects of the biology of the cercaria and metacercaria of Stephanostomum baccatum (Nicoll, 1907) Manter, 1934 (Digenea: Acanthocolpidae). Journal of Fish Biology, 7, 247-256.

Maddison, D.R. \& Maddison, W.P. (2005) MacClade 4: Analysis of phylogeny and character evolution. Version 4.08. Sinauer Associates, Sunderland, Massachusetts.

Madhavi, R. \& Shameem, U. (1993) Cercariae and metacercariae of Stephanostomum cloacum (Trematoda: Acanthocolpidae). International Journal for Parasitology, 23, 341-347.

Maillard, C. (1975) Cycle evolutif de Paratimonia gobii Prevot et Bartoli, 1967 (Trematoda: Monorchiidae). Acta tropica, 32, 327-333.

Marasaev, S.F. (1984) Three types of cercariae from benthic molluscs of the central and south-east parts of the Barents Sea. In: Polyansky, Y.I., Galaktionov, K.V. \& Dobrovolsky, A.A. (Eds.) Ecological-parasitological investigations of northern seas. Apatity: Kola Branch of Academy of Sciences of the USSR, Murmansk Biological Institute, Murmansk, pp. 51-59.

Martin, W.E. (1939) Studies on the trematodes of Woods Hole: II. The life cycle of Stephanostomum tenue (Linton). Biological Bulletin, 77, 65-73.

Miller, H.M., Jr. \& Northup, F.E. (1926) The seasonal infestation of Nassa obsoleta (Say) with larval trematodes. Biological Bulletin, 50, 490-508.

Miller, T.L. \& Cribb, T.H. (2009) Gynichthys diakidnus n. g., n. sp. (Digenea: Cryptogonimidae) from the grunt Plectorhinchus gibbosus (Lacépède, 1802) (Perciformes: Haemulidae) off the Great Barrier Reef, Australia. Systematic Parasitology, 74, 103-112.

Morgan, J.A.T. \& Blair, D. (1995) Nuclear rDNA ITS sequence variation in the trematode genus Echinostoma: an aid to establishing relationships within the 37-collar-spine group. Parasitology, 111, 609-615.

Morgan, J.A.T. \& Blair, D. (1998) Trematode and monogenean rRNA ITS2 secondary structures support a four-domain model. Journal of Molecular Evolution, 47, 406-419.

Müller, T., Philippi, N., Dandekar, T., Schultz, J. \& Wolf, M. (2007) Distinguishing species. RNA, 13, $1469-1472$.

Nasir, P. (1976) Marine larval trematodes. I. Cercariae criollisimae: five new Venezuelan species and redescription of 
Parorchis acanthus (Nicoll, 1906) Nicoll, 1907. Rivista di Parassitologia, 37, 287-302.

Posada, D. \& Crandall, K.A. (1998) Modeltest: testing the model of DNA substitution. Bioinformatics, 14, 817-818.

Ronquist, F. \& Huelsenbeck, J.P. (2003) MRBAYES 3: Bayesian phylogenetic inference under mixed models. Bioinformatics, 19, 1572-1574.

Schultz, J., Maisel, S., Gerlach, D., Müller, T. \& Wolf, M. (2005) A common core of secondary structure of the internal transcribed spacer 2 (ITS2) throughout the Eukaryota. RNA, 11, 361-364.

Seibel, P.N., Müller, T., Dandekar, T. \& Wolf, M. (2008) Synchronous visual analysis and editing of RNA sequence and secondary structure alignments using 4SALE. BMC Research Notes, 1, 91.

Shimura, S. (1984) A new species of marine cercaria Cercaria itoi sp. nov. from the spindle shell Fusinus perplexus from Kanagawa Prefecture, Japan. Fish Pathology, 18, 179-183.

Stunkard, H.W. (1961) Cercaria dipterocerca Miller and Northup, 1926 and Stephanostomum dentatum (Linton, 1900) Manter, 1931. Biological Bulletin, 120, 221-237.

Wardle, W.J. (1975) Cercaria anadarae sp. n. parasitizing a bivalve mollusc, Anadara brasiliana (Lamarck), from the northwest Gulf of Mexico. Journal of Parasitology, 61, 1048-1049.

Wolf, M., Friedrich, J., Dandekar, T. \& Müller, T. (2005) CBCAnalyzer: inferring phylogenies based on compensatory base changes in RNA secondary structures. In Silico Biology, 5, 0027.

Wolfgang, R.W. (1955) Studies of the trematode Stephanostomum baccatum (Nicoll, 1907). III. Its life cycle. Canadian Journal of Zoology, 33, 113-128.

Yamaguti, S. (1971) Synopsis of digenetic trematodes of vertebrates. Keigaku Publishing Co., Tokyo, 1074 pp.

Yamaguti, S. (1975) A synoptical review of life histories of digenetic trematodes of vertebrates: with special reference to the morphology of their larval forms. Keigaku Publishing Co., Tokyo, 590 pp.

Zuker, M. (2003) Mfold web server for nucleic acid folding and hybridization prediction. Nucleic Acids Research, 31, 3406-3415. 